\title{
A novel polymeric catalyst for the one-pot synthesis of 2,4,5-triaryl-1H-imidazoles
}

\author{
ALI MOHAMMADI $^{\mathrm{a}, *}$ HOSSEIN KESHVARI $^{\mathrm{b}}$, REZA SANDAROOS $^{\mathrm{c}}$, HAMED ROUHI $^{\mathrm{a}}$ \\ and ZEINALABEDIN SEPEHR ${ }^{\mathrm{b}}$ \\ ${ }^{a}$ Department of Chemistry, Faculty of Science, Ferdowsi University of Mashhad, P.O. Box 91775, \\ Mashhad, Iran \\ ${ }^{b}$ Department of Chemistry, Tarbiat Moallem University of Sabzevar, P.O. Box 9617976487, Sabzevar, Iran \\ ${ }^{\mathrm{c}}$ Department of Chemistry, Faculty of Science, University of Birjand, P.O. Box 97175/615, Birjand, Iran \\ e-mail: a.mohammady62@yahoo.com
}

MS received 8 August 2011; revised 29 November 2011; accepted 20 January 2012

\begin{abstract}
An efficient synthesis of 2,4,5-trisubstituted imidazoles is achieved by three component cyclocondensation of benzil or benzoin, aldehyde and ammonium acetate by using novel polymeric catalyst [poly(AMPS-co-AA)] under solvent-free conditions. The key advantages of this process are high yields, shorter reaction times, easy work-up, purification of products by non-chromatographic method and the reusability of the catalyst.
\end{abstract}

Keywords. 2,4,5-Trisubstituted imidazoles; solvent-free synthesis; multicomponent reaction; poly(AMPS-co-AA); heterogeneous catalysts.

\section{Introduction}

Multicomponent reactions (MCRs) have drawn great interest in modern organic synthesis and medicinal chemistry because they are one-pot processes bringing together three or more components and show high atom economy and high selectivity. ${ }^{1,2}$ MCRs have contributed in convergent synthesis of complex and important organic molecules from simple and readily available starting materials, and have emerged as powerful tools for drug discovery. ${ }^{3,4}$ The imidazole nucleus is a fertile source of biologically important molecules. Compounds containing imidazole moiety have many pharmacological properties and play important roles in biochemical processes. They are well-known as inhibitors of P38MAP kinase, fungicides, herbicides, antiinflammatory agents, antithrombotic agents, plant growth regulators and therapeutic agents. In addition, they are used in photography as photosensitive compounds. Some substituted triarylimidazoles are selective antagonists of the glucagons receptor and inhibitors of IL-1 biosynthesis. ${ }^{5}$ Radziszewski and Jaap proposed the first synthesis of the imidazole core in 1882, starting

*For correspondence from 1,2-dicarbonyl compounds, aldehydes and ammonia to obtain 2,4,5-triphenylimidazole. ${ }^{6,7}$ There are several methods for the synthesis of 2,4,5-triarylimidazoles using $\mathrm{ZrCl}_{4},{ }^{8}$ zeolites HY/silica gel, ${ }^{9} \mathrm{NaHSO}_{3},{ }^{10}$ sulphanilic acid, ${ }^{11}$ iodine, ${ }^{12}$ ceric ammonium nitrate, ${ }^{13}$ oxalic acid, ${ }^{14}$ ionic liquids ${ }^{15}$ and also by microwave irradiation using acetic acid. ${ }^{16}$ Each of the above methods for this reaction has its own merits, while some of the methods are plagued by the limitations of poor yield, longer reaction time, difficult work-up and effluent pollution. ${ }^{5}$ Therefore, the development of a new mild method to overcome these disadvantages still remains a challenge for organic chemists. One of the aims we have in mind is to introduce a new catalyst for synthesis of 2,4,5-trisubstituted imidazoles with cost effectiveness and mild condition in high yields. In 1963, Merrifield introduced a modified technique that overcame the problems associated with classical multistep synthesis. This technique has been used in the production of large amount of products. However, recently, the chemistry of functional polymers has received great attention and became a practical method for the efficient preparation of novel chemical libraries. ${ }^{17}$ Polymeric reagents have recently been developed for use in simple processes such as epoxidation, oxidation, acylation, halogenation, and Wittig reactions. In all of these applications, the advantages of the selectivity, insolubility, and reusable capacity of the polymeric reagent 


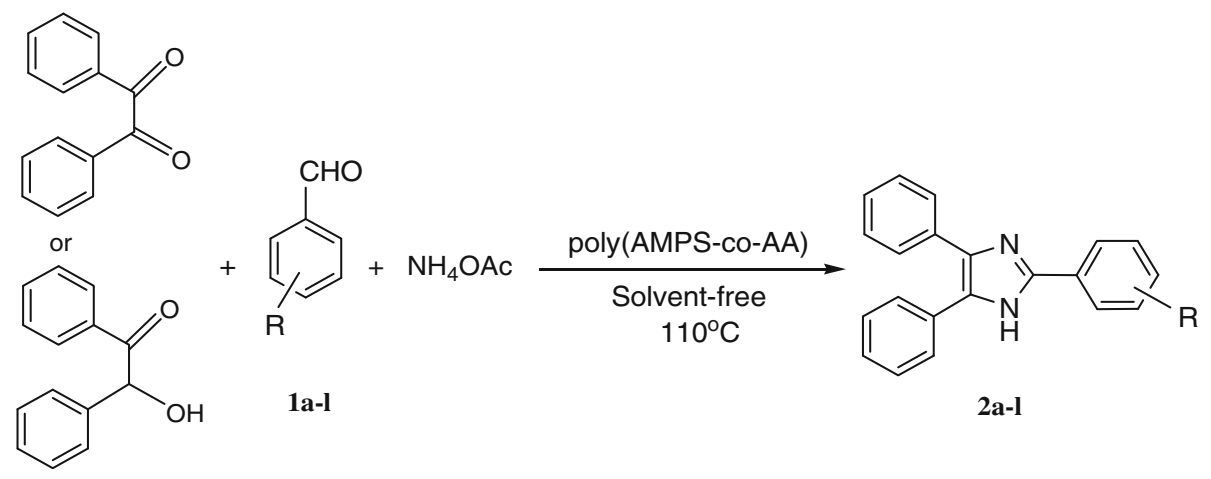

Figure 1. Crosslinked poly (AMPS-co-AA) catalysed synthesis of 2,4,5-trisubstituted imidazole.

are taken. ${ }^{18}$ Polymers are a large family of compounds that provide a variety of compositions and properties that can be useful in catalysis. Insoluble polymers offer suitable substrates for the heterogenization of homogeneous catalysis, but even the attachment of catalysts to soluble polymers have advantages, since being macromolecules, these polymers can easily be separated from the reaction mixture by the addition of a co-solvent or by ultrafiltration. ${ }^{19}$

With these assumptions, we report here the solventfree synthesis of 2,4,5-trisubstituted imidazoles using poly(2-acrylamido-2-methyl propane sulphonic acid) (AMPS) crosslinked with $N, N^{\prime}$-methylene bisacrylamide (MBA) as a novel catalyst under classical heating (figure 1).

We examined a wide variety of aromatic aldehydes with various substituents to establish the catalytic importance of this catalyst for this reaction. A wide range of ortho-, meta- and para-substituted aromatic aldehydes undergo this one-pot multicomponent synthesis with benzil or benzoin and ammonium acetate to afford 2,4,5-trisubstituted imidazoles in good yields.

\section{Experimental}

Melting points were measured with an Electrothermal 9100 apparatus. IR spectra were recorded with a Varian 3100 FTIR spectrometer. CHN analyses were performed on Exeter Analytical Inc. 'Model CE-400 CHN Analyzer'. ${ }^{1} \mathrm{H}$ and ${ }^{13} \mathrm{C}$ NMR spectra were recorded with a BRUKER DRX-400 AVANCE spectrometer at $298^{\circ} \mathrm{K}$ and $75.47 \mathrm{MHz}$, respectively. NMR spectra were obtained on solutions in DMSO- $\mathrm{d}_{6}$. All the products were known compounds, ${ }^{20-26}$ which were characterized by IR and ${ }^{1} \mathrm{H}$ NMR spectral data and their melting point compared with literature reports.

\section{General procedure}

\subsection{Preparation and reusability of the crosslinked poly (AMPS-co-AA) catalyst}

Crosslinked poly (AMPS-co-AA) was prepared according to the literature, ${ }^{27}$ by polymerization of 2acrylamido-2-methyl-1-propane sulphonic acid (AMPS) and acrylic acid (AA) as the monomers in water, in the presence of a crosslinking agent $N, N^{\prime}$-methylene bisacrylamide (MBA) and potassium persulphate (KPS) as a free radical initiator (figure 2). The structure of the polymer was characterized by FTIR analysis. When the crosslinked poly (AMPS-co-AA) was used in the reaction and the reaction was completed, the polymeric catalyst was separated by simple filtration by diluting with hot ethanol and then oven dried in $110^{\circ} \mathrm{C}$ for $24 \mathrm{~h}$. The recycled catalyst was employed consecutively for three reactions and no significant loss in its efficiency was observed.

\subsection{General procedure for preparation of $\mathbf{2 a - 1}$}

A mixture of aldehyde $(1 \mathrm{mmol})$, benzil or benzoin $(1 \mathrm{mmol})$, ammonium acetate $(5 \mathrm{mmol})$ and crosslinked poly (AMPS-co-AA) $(0.03 \mathrm{~g})$, as a catalyst, in a $20 \mathrm{ml}$ glass tube was stirred at $110^{\circ} \mathrm{C}$ for $25-35 \mathrm{~min}$. After completion of the reaction, appropriate amounts of hot $\mathrm{EtOH}(96 \%)$ was added and the mixture stirred for $10 \mathrm{~min}$. then, the catalyst separated by filtration. The filtrate was concentrated in vacuo to remove the ethanol. The residue was washed with cold water and crystallized from hot ethanol to afford the pure products.

\subsection{Selected spectral data}

3.3.a. 2,4,5-Triphenyl-1H-imidazole (2a): Yield: (92\%, $272 \mathrm{mg}$ ); Mp 273-275 $\mathrm{C}$; FTIR $\left(\mathrm{KBr}, \mathrm{cm}^{-1}\right)$ : 3451, 

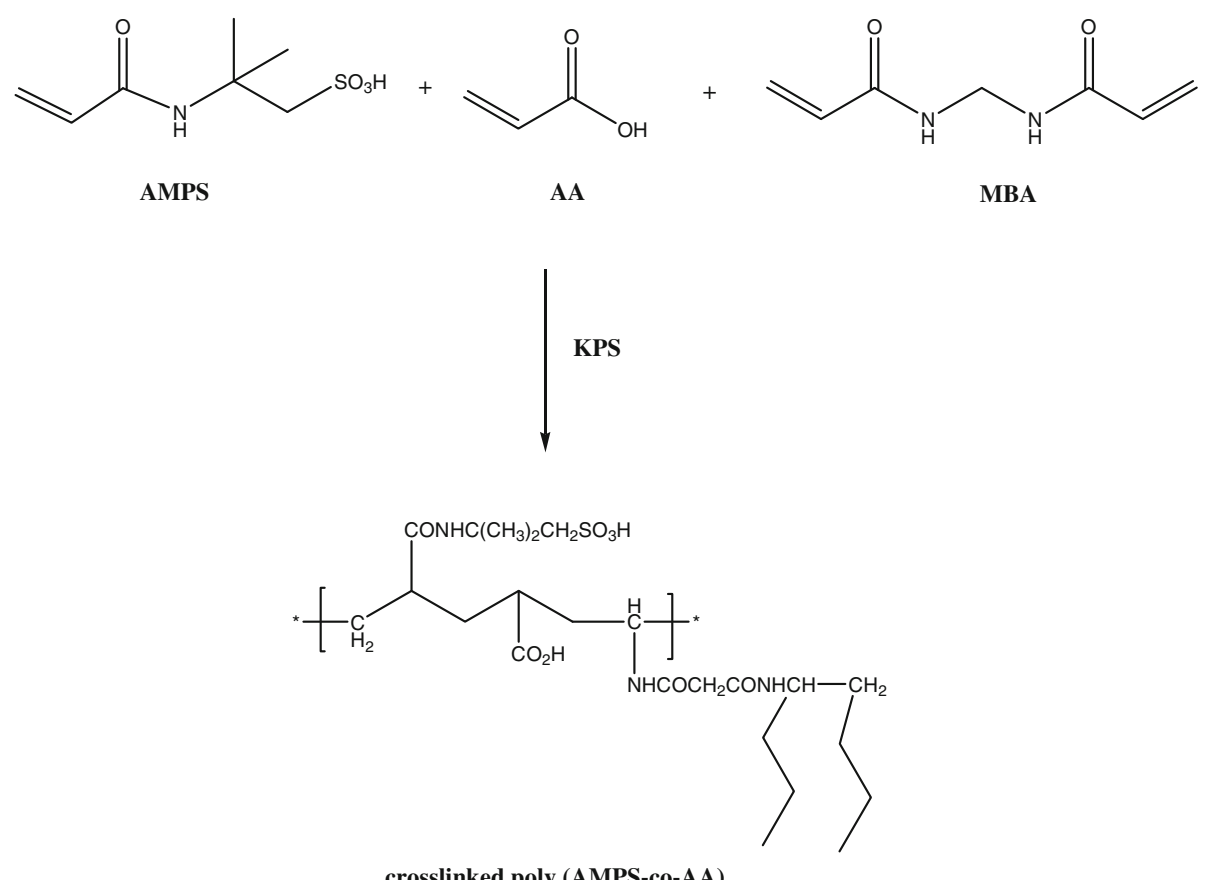

Figure 2. Preparation of crosslinked poly (AMPS-co-AA).

2856, 1636, 1490; ${ }^{1} \mathrm{H}$ NMR (400 MHz, DMSO-d 6 ): $\delta 12.69(\mathrm{~s}, 1 \mathrm{H}), 8.09(\mathrm{~d}, J=7.7 \mathrm{~Hz}, 2 \mathrm{H}), 7.56-7.22$ $(\mathrm{m}, 13 \mathrm{H}) ;{ }^{13} \mathrm{C}$ NMR $\left(75 \mathrm{MHz}, \mathrm{DMSO}-\mathrm{d}_{6}\right): \delta 145.6$, $137.2,135.2,131.2,130.4,128.7,128.5,128.3,128.2$, 127.8, 127.2, 126.6, 125.3; Anal. Calcd for $\mathrm{C}_{21} \mathrm{H}_{16} \mathrm{~N}_{2}$ : C, 85.11; H, 5.44; N, 9.45. Found: C, 85.18; H, 5.49; $\mathrm{N}, 9.33$.

3.3.b. 2-(4-Chlorophenyl)-4,5-diphenyl-1H-imidazole (2b): Yield: $(95 \%, 313 \mathrm{mg})$; Mp 264-266 ${ }^{\circ} \mathrm{C}$; FTIR $\left(\mathrm{KBr}, \mathrm{cm}^{-1}\right)$ : 3452, 3065, 1635, 1323; ${ }^{1} \mathrm{H}$ NMR $\left(400 \mathrm{MHz}, \mathrm{DMSO}-\mathrm{d}_{6}\right): \delta 12.78(\mathrm{~s}, 1 \mathrm{H}), 8.11(\mathrm{~d}, J=$ $8.4 \mathrm{~Hz}, 2 \mathrm{H}), 7.56-7.23(\mathrm{~m}, 12 \mathrm{H}) ;{ }^{13} \mathrm{C}$ NMR $(75 \mathrm{MHz}$, DMSO-d $\left.{ }_{6}\right): \delta 146.3,130.3,129.9,129.2,128.5,127.4$, 127.0, 126.4, 125.5, 125.2, 123.3, 116.3; Anal. Calcd for $\mathrm{C}_{21} \mathrm{H}_{15} \mathrm{~N}_{2} \mathrm{Cl}$ : C, 76.24; H, 4.57; N, 8.47. Found: C, 76.20; H, 4.61; N, 8.41.

3.3.c. 4,5-Diphenyl-2-p-tolyl-1H-imidazole (2c): Yield: $(85 \%, 263 \mathrm{mg})$; Mp $231-232^{\circ} \mathrm{C}$; FTIR ( $\mathrm{KBr}$, $\left.\mathrm{cm}^{-1}\right): 3449,3034,1611,1495,1320 ;{ }^{1} \mathrm{H}$ NMR $\left(400 \mathrm{MHz}, \mathrm{DMSO}_{\mathrm{d}}\right): \delta 12.59(\mathrm{~s}, 1 \mathrm{H}), 7.98(\mathrm{~d}, J=$ $8.2 \mathrm{~Hz}, 2 \mathrm{H}), 7.54-2.21(\mathrm{~m}, 12 \mathrm{H}), 2.35(\mathrm{~s}, 3 \mathrm{H}) ;{ }^{13} \mathrm{C}$ NMR $(75 \mathrm{MHz}$, DMSO-d 6 ): $\delta$ 145.6, 137.6, 136.9, 135.2, 131.1, 129.2, 128.6, 128.3, 128.1, 127.9, 127.6, 127.0, 126.4, 125.1, 20.8; Anal. Calcd for $\mathrm{C}_{22} \mathrm{H}_{18} \mathrm{~N}_{2}$ : C, 85.13; H, 5.85; N, 9.03. Found: C, 85.23; H, 5.79; N, 8.97 . 3.3.d. 2-(4-Methoxyphenyl)-4,5-diphenyl-1H-imidazole (2d): Yield: $(85 \%, 277 \mathrm{mg})$; Mp 230-233 ${ }^{\circ} \mathrm{C}$; FTIR $\left(\mathrm{KBr}, \mathrm{cm}^{-1}\right)$ : 3425, 3029, 2956, 1610, 1495, 1249; ${ }^{1} \mathrm{HNMR}\left(400 \mathrm{MHz}, \mathrm{DMSO}-\mathrm{d}_{6}\right): \delta 12.50(\mathrm{~s}, 1 \mathrm{H}), 8.03$ $(\mathrm{d}, J=8.5 \mathrm{~Hz}, 2 \mathrm{H}), 7.50-7.05(\mathrm{~m}, 12 \mathrm{H}), 3.82(\mathrm{~s}, 3 \mathrm{H})$; ${ }^{13} \mathrm{C}$ NMR (75 MHz, DMSO-d $\left.{ }_{6}\right): \delta 159.5,145.7,128.4$, 127.7, 126.8, 123.1, 114.1, 55.2; Anal. Calcd for $\mathrm{C}_{22} \mathrm{H}_{18} \mathrm{~N}_{2} \mathrm{O}$ : C, 80.96; H, 5.56; N, 8.58. Found: C, $80.90 ; \mathrm{H}, 5.51 ; \mathrm{N}, 8.63$.

3.3.e. 4-(4,5-Diphenyl-1H-imidazol-2-yl)-phenol (2e): Yield: (90\%, $280 \mathrm{mg})$; Mp $265-267^{\circ} \mathrm{C}$; FTIR (KBr, $\left.\mathrm{cm}^{-1}\right)$ : 3590, 3454, 3284, 3064, 1701, 1283; ${ }^{1} \mathrm{H}$ NMR $\left(400 \mathrm{MHz}, \mathrm{DMSO}-\mathrm{d}_{6}\right): \delta 12.40(\mathrm{~s}, 1 \mathrm{H}), 9.75(\mathrm{~s}, 1 \mathrm{H})$, $7.90(\mathrm{~d}, J=8.3 \mathrm{~Hz}, 2 \mathrm{H}), 7.54-7.21(\mathrm{~m}, 10 \mathrm{H}), 6.86(\mathrm{~d}$, $2 \mathrm{H}) ;{ }^{13} \mathrm{C}$ NMR $\left(75 \mathrm{MHz}, \mathrm{DMSO}-\mathrm{d}_{6}\right): \delta 157.7,146.1$, 136.6, 135.4, 131.3, 128.6, 128.3, 127.5, 127.3, 127.0, 126.8, 126.3, 121.6, 115.4; Anal. Calcd for $\mathrm{C}_{21} \mathrm{H}_{16} \mathrm{~N}_{2} \mathrm{O}$ : C, 80.75; H, 5.16; N, 8.97. Found: C, 80.79; H, 5.22; $\mathrm{N}, 8.91$.

3.3.f. 2-(4-Fluorophenyl)-4,5-diphenyl-1H-imidazole (2f): Yield: $(86 \%, 270 \mathrm{mg})$; Mp $250-252^{\circ} \mathrm{C}$; FTIR $\left(\mathrm{KBr}, \mathrm{cm}^{-1}\right): 3316,2993,2470,1660,1210,1169,874$, 719, 639; ${ }^{1} \mathrm{H}$ NMR (400 MHz, DMSO-d $\left.{ }_{6}\right): \delta 12.82(\mathrm{~s}$, $1 \mathrm{H}), 8.28(\mathrm{~d}, J=7.1 \mathrm{~Hz}, 2 \mathrm{H}), 7.55-7.03(\mathrm{~m}, 12 \mathrm{H})$; ${ }^{13} \mathrm{C}$ NMR (75 MHz, DMSO-d 6 ): $\delta 165.4,137.3,131.1$, $129.8,128.9,127.7,127.2,126.6,125.9,125.5,124.1$, 
Table 1. Optimization one-pot synthesis of trisubstituted imidazoles under classical heating conditions. $^{\text {a }}$

\begin{tabular}{lcccc}
\hline Entry & poly(AMPS-co-AA $)(\mathrm{g})$ & $\mathrm{T}\left({ }^{\circ} \mathrm{C}\right)$ & Time $(\mathrm{min})$ & Yield $(\%)$ \\
\hline 1 & 0.01 & 100 & 60 & 50 \\
2 & 0.01 & 110 & 55 & 56 \\
3 & 0.01 & 120 & 45 & 70 \\
4 & 0.01 & 130 & 40 & 75 \\
5 & 0.02 & 110 & 50 & 70 \\
6 & 0.02 & 120 & 30 & 78 \\
7 & 0.02 & 130 & 35 & 80 \\
8 & 0.03 & 110 & 25 & 95 \\
9 & 0.03 & 120 & 25 & 95 \\
10 & 0.03 & 130 & 30 & 85 \\
11 & 0.04 & 110 & 30 & 90 \\
\hline
\end{tabular}

${ }^{a}$ Benzil (1 mmol), 4-chloro benzaldehyde $(1 \mathrm{mmol})$ and ammonium acetate $(5 \mathrm{mmol})$

117.4; Anal. Calcd for $\mathrm{C}_{21} \mathrm{H}_{15} \mathrm{~N}_{2} \mathrm{~F}$ : C, 76.27; H, 4.54; N, 8.41. Found: C, 76.22; H, 4.60; N, 8.43.

3.3.g. 2-(2-Methoxyphenyl)-4,5-diphenyl-1H-imidazole (2g): Yield: $(85 \%, 277 \mathrm{mg})$; Mp 212-213 ${ }^{\circ} \mathrm{C}$; FTIR $\left(\mathrm{KBr}, \mathrm{cm}^{1}\right): 3430,3038,2950,1615,1495 ;{ }^{1} \mathrm{H}$ NMR $\left(400 \mathrm{MHz}, \mathrm{DMSO}_{6} \mathrm{~d}_{6}\right): \delta 11.82,(\mathrm{~s}, 1 \mathrm{H}), 8.02(\mathrm{~d}, J=$ $7.4 \mathrm{~Hz}, 1 \mathrm{H}), 7.53-7.07(\mathrm{~m}, 13 \mathrm{H}), 3.92(\mathrm{~s}, 3 \mathrm{H}) ;{ }^{13} \mathrm{C}$ NMR $(75 \mathrm{MHz}$, DMSO-d 6 ): $\delta$ 158.2, 146.2, 128.3 , 127.5, 125.4, 123.8, 115.4, 55.3; Anal. Calcd for $\mathrm{C}_{22} \mathrm{H}_{18} \mathrm{~N}_{2} \mathrm{O}$ : $\mathrm{C}, 80.96 ; \mathrm{H}, 5.56 ; \mathrm{N}, 8.58$. Found: $\mathrm{C}$, $80.90 ; \mathrm{H}, 5.63 ; \mathrm{N}, 8.51$.

3.3.h. 2-(3-Nitrophenyl)-4,5-diphenyl-1H-imidazole (2i): Yield: $(85 \%, 289 \mathrm{mg})$; Mp 301-302 ${ }^{\circ} \mathrm{C}$; FTIR
$\left(\mathrm{KBr}, \mathrm{cm}^{-1}\right): 3448,3068,1526,1350 ;{ }^{1} \mathrm{H}$ NMR $\left(400 \mathrm{MHz}, \mathrm{DMSO}-\mathrm{d}_{6}\right): \delta 13.12(\mathrm{~s}, 1 \mathrm{H}), 8.90(\mathrm{~s}, 1 \mathrm{H})$, $8.56(\mathrm{~d}, J=7.4 \mathrm{~Hz}, 1 \mathrm{H}), 8.21(\mathrm{~d}, J=7.6 \mathrm{~Hz}$, $1 \mathrm{H}), 7.81(\mathrm{~d}, J=7.6 \mathrm{~Hz}, 1 \mathrm{H}), 7.56-7.30(\mathrm{~m}, 10 \mathrm{H})$; ${ }^{13} \mathrm{C}$ NMR (75 MHz, DMSO-d ${ }_{6}$ ): $\delta 148.4,143.4,131.8$, 131.2, 130.4, 128.7, 128.4, 127.1, 122.6, 119.4; Anal. Calcd for $\mathrm{C}_{21} \mathrm{H}_{15} \mathrm{~N}_{3} \mathrm{O}_{2}$ : C, 73.89; H, 4.43; N, 12.31 . Found: C, 73.84; H, 4.47; N, 12.39 .

\section{Results and discussion}

Several methods are used in the synthesis of these trisubstituted imidazoles and their derivatives. In addition, the synthesis of these heterocycles has been usually carried out in polar organic solvents such as ethanol, methanol, acetic acid, DMF and DMSO leading to complex isolation and recovery procedures. These processes also generate waste containing catalyst and solvent, which have to be recovered, treated and disposed of. The toxicity and volatile nature of many organic solvents, particularly chlorinated hydrocarbons that are widely used in huge amounts for organic reactions have posed a serious threat to the environment. ${ }^{28}$ Thus, design of solvent-free catalytic reaction has received more attention in recent times in the area of green synthesis. ${ }^{29}$

Efficiency of this reaction is mainly affected by the amount of catalyst, temperature and reaction time. For getting the best conditions, initially we started the condensation of benzil ( $1 \mathrm{mmol})$, 4-chloro benzaldehyde $(1 \mathrm{mmol})$ and ammonium acetate $(5 \mathrm{mmol})$ in the presence of crosslinked poly (AMPS-co-AA) $(0.01 \mathrm{~g})$ as a catalyst at $100^{\circ} \mathrm{C}$ for $55 \mathrm{~min}$, which led to low yield

Table 2. Synthesis of 2,4,5-triaryl-1H-imidazoles (2a-l) using crosslinked poly(AMPS-co-AA) (0.03 g) under solvent-free conditions.

\begin{tabular}{|c|c|c|c|c|c|c|c|}
\hline \multirow[b]{2}{*}{ Products $^{\mathrm{a}}$} & \multirow[b]{2}{*}{$R$} & \multicolumn{2}{|c|}{ Time (min) } & \multicolumn{2}{|c|}{ Yields $(\%)^{\mathrm{b}}$} & \multicolumn{2}{|c|}{$\mathrm{Mp} /{ }^{\circ} \mathrm{C}$} \\
\hline & & Benzil & Benzoin & Benzil & Benzoin & Found & Reported \\
\hline $2 \mathbf{a}$ & $4-\mathrm{H}$ & 25 & 25 & 92 & 90 & $273-275$ & $272-274^{20}$ \\
\hline $2 b$ & $4-\mathrm{Cl}$ & 25 & 25 & 95 & 90 & $264-266$ & $262-264^{20}$ \\
\hline $2 c$ & $4-\mathrm{CH}_{3}$ & 25 & 30 & 85 & 80 & $231-232$ & $230-232^{21}$ \\
\hline $2 d$ & 4-OMe & 30 & 35 & 85 & 80 & $230-233$ & $228-231^{20}$ \\
\hline $2 \mathrm{e}$ & $4-\mathrm{OH}$ & 35 & 35 & 90 & 85 & $265-267$ & $268-270^{22}$ \\
\hline $2 f$ & $4-\mathrm{F}$ & 35 & 35 & 86 & 80 & $250-252$ & $250-251^{23}$ \\
\hline $2 g$ & 2-OMe & 30 & 30 & 85 & 85 & $212-213$ & $210-211^{22}$ \\
\hline $2 \mathrm{~h}$ & $3-\mathrm{Br}$ & 30 & 30 & 90 & 85 & $232-233$ & $231-233^{24}$ \\
\hline $2 \mathrm{i}$ & $3-\mathrm{NO}_{2}$ & 35 & 35 & 85 & 80 & $301-302$ & $>300^{24}$ \\
\hline $2 \mathrm{j}$ & $2-\mathrm{CH}_{3}$ & 30 & 35 & 90 & 88 & 201-204 & $205-207^{25}$ \\
\hline $2 \mathbf{k}$ & $4-\mathrm{Br}$ & 25 & 25 & 92 & 85 & $264-266$ & $263-265^{21}$ \\
\hline 21 & 3,4-diOMe & 30 & 30 & 85 & 80 & $217-219$ & $216-218^{26}$ \\
\hline
\end{tabular}

${ }^{a}$ All the isolated products were characterized on the basis of their physical properties and IR, ${ }^{1} \mathrm{H}-$ and ${ }^{13} \mathrm{C}-\mathrm{NMR}$ spectral analysis and by direct comparison with authentic materials; ${ }^{b}$ Isolated yields 
$(50 \%)$ of 2,4,5-trisubstituted imidazole. To enhance the yield of the desired product the temperature of the reaction was increased to $130^{\circ} \mathrm{C}$. With increasing the temperature, the reaction time decreased and the productivity of the reaction increased but was not very high. Hence, it was thought worthwhile to carry out the reaction in the presence of higher amount of the catalyst. As indicated in table 1, Maximum yield was obtained (95\%) when the reaction was loaded with $0.03 \mathrm{~g}$ of the catalyst at $110^{\circ} \mathrm{C}$. A further increasing of catalyst loading did not affect the yield (entry 11, table 1).

After optimizing the conditions, we applied this catalyst for synthesis of trisubstituted imidazoles by using different aromatic aldehydes with a wide range of ortho-, meta- and para-substitutions under solvent-free classical heating conditions to establish the catalytic importance of crosslinked poly(AMPS-co-AA) for this reaction.

Generally, the synthetic procedure involves stirring the mixture of aldehyde $(1 \mathrm{mmol})$, benzil $(1 \mathrm{mmol})$, ammonium acetate $(5 \mathrm{mmol})$ and crosslinked poly (AMPS-co-AA) $(0.03 \mathrm{~g})$ for $25-35 \mathrm{~min}$ at $110^{\circ} \mathrm{C}$. The corresponding results are given in table 2 . We found that the reaction proceeded very efficiently either electronreleasing or electron-withdrawing substituents on aryl ring of aldehyde.

Also, due to direct use of benzoin rather than benzil in the synthesis of imidazoles a significant improvement

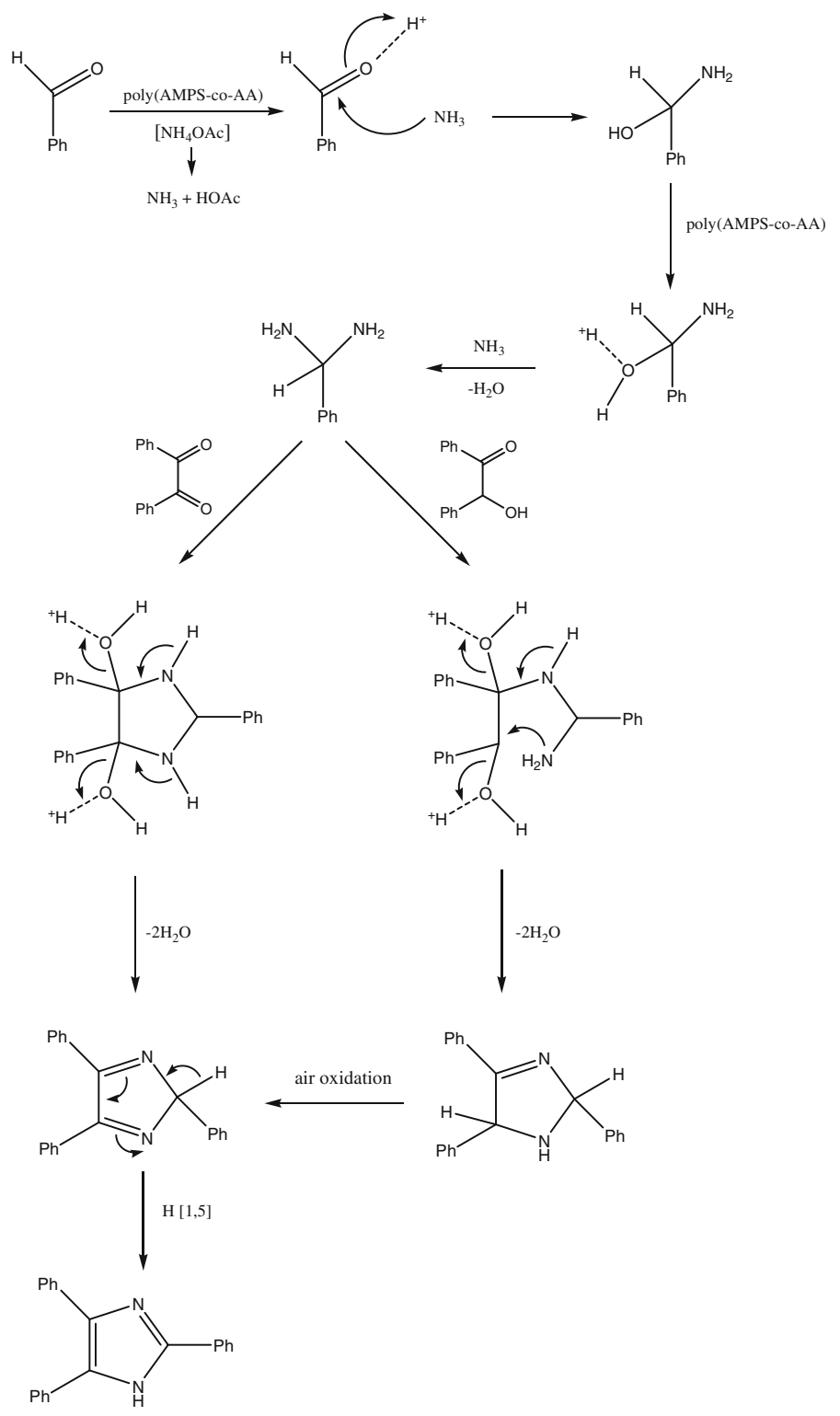

Figure 3. Probable mechanism for the formation of triarylimidazoles using benzil or benzoin, ammonium acetate, aromatic aldehydes and poly (AMPS-co-AA) as catalyst. 
in the synthesis toward the greener chemistry is represented. We have repeated the reaction with benzoin instead of benzil and the desired product has been efficiently produced. As indicated in table 2 , when we used benzoin instead of benzyl, the reaction time increased and also the yield of the reaction decreased partially.

Possible mechanism for the crosslinked poly (AMPS-co-AA) catalysed synthesis of trisubstituted imidazoles has been given in figure $3{ }^{30}$ In summary, this paper describes a convenient and efficient process for the solvent-free synthesis of trisubstituted imidazoles through the three-components coupling of benzil or benzoin, aldehydes and ammonium acetate using crosslinked poly(AMPS-co-AA) as a catalyst. Reaction profile is very clean and no by-products are formed. All the synthesized imidazoles have been characterized on the basis of elemental and spectral studies. We believe that this procedure is convenient, economic, and a user-friendly process for the synthesis of trisubstituted imidazoles of biological and medicinal importance.

\section{Conclusion}

We have been able to introduce an efficient and environmentally friendly approach for the synthesis of biologically active trisubstituted imidazoles via condensation of benzil or benzoin with various aromatic aldehydes and ammonium acetate using crosslinked poly (AMPSco-AA) as a catalyst. High yields, easy work-up, purification of compounds by non-chromatographic method (crystallization only) and the reusability of the catalyst are the key advantages of this method.

\section{References}

1. D'Souza D M and Mueller T J J 2007 Chem. Soc. Rev. 361095

2. Domling A 2006 Chem. Rev. 10617

3. Tempest P A 2005 Curr. Opin. Drug. Disc. Dev. 8 776

4. Kalinski C, Lemoine H, Schmidt J, Burdack C, Kolb J, Umkehrer M and Ross G 2008 Synlett 244007
5. Gadekar L S, Mane S R, Katkar S S, Arbad B R and Lande M K 2009 Cent. Eur. J. Chem. 7550

6. Radziszewski B 1882 Chem. Ber. 151493

7. Japp F and Robinson H 1882 Chem. Ber. 151268

8. Sharma G, Jyothi Y and Lakshmi P 2006 Synth. Commun. 362991

9. Balalaie S, Arabanian A and Hashtroudi M 2000 Mont. Fur. Chem. 131945

10. Sangshetti J, Kokare N, Kotharkar A and Shinde D 2008 Mont. Fur. Chem. 139125

11. Mohammed A, Lokare N, Sangshetti J and Shinde D 2007 J. Korean Chem. Soc. 51418

12. Kidwai M, Mothsra P, Bansal V and Goyal R 2006 Mont. Fur. Chem. 1371189

13. Sangshetti J N, Kakare N D, Kotharkar S A and Shinde D B 2008 J. Chem. Sci. 120463

14. Kokare N D, Sangshetti J N and Shinde D B 2007 Synthesis 2829

15. Siddiqui S, Narkhede U, Palimkar S, Daniel T, Lahoti R and Srinivasan K 2005 Tetrahedron 613539

16. Zhou J F, Song Y Z, Zhu Y L and Tu S J 2005 Synth. Commun. 351369

17. Karimi Zarchi M A and Ebrahimi N 2011 J. Appl. Polym. Sci. 1212621

18. Dhiman P K, Mahajan R K and Kaur I 2011 J. Appl. Polym. Sci. 1212584

19. Albéniz A C and Carrera N 2011 Eur. J. Inorg. Chem. 2347

20. Kidwai M, Mothsra P, Bansal V and Goyal R 2006 Monatsh Chem. 1371189

21. Safari J, Dehgan Khalili S and Banitaba S H 2010 J. Chem. Sci. 122437

22. Sangshetti J N, Shinde D B, Kokare N D and Kotharkar S A 2008 Monatsh Chem. 139125

23. Yu C, Lei M, Su W and Xie Y 2007 Synth. Commun. 37 3301

24. Samai S, Nandi G C, Singh P and Singh M S 2009 Tetrahedron 6510155

25. White D M and Sonnenberg J 1964 J. Org. Chem. 29 1926

26. Zhou J F, Song Y Z and Tu S J 2005 Synth. Commun. 35 1369

27. Atta A M, Abd El Wahab Z H, El Shafey Z A, Zidan W I and Akl Z F 2010 J. Disp. Sci. Tech. 311415

28. Nelson W M, Anastas P T and Williamson T C 1998 Green chemistry (Oxford: Oxford University)

29. Tanaka K and Toda F 2000 Chem. Rev. 1001025

30. Shelke K F, Sapkal S B, Sonar S S, Madje B R, Shingate B B and Shingare M S 2009 Bull. Korean Chem. Soc. 30 1057 